\title{
Does the invisible hand have a green thumb? Incentives, linkages, and the creation of wealth out of industrial waste in Victorian England
}

article version: accepted manuscript

Desrochers, Pierre

DESROCHERS, P. (2009), Does the invisible hand have a green thumb? Incentives, linkages, and the creation of wealth out of industrial waste in Victorian England. Geographical Journal, 175: 3-16

\footnotetext{
"This is the peer reviewed version of the following article: DESROCHERS, P. (2009), Does the invisible hand have a green thumb? Incentives, linkages, and the creation of wealth out of industrial waste in Victorian England. Geographical Journal, 175: 3-16 which has been published in final form at 10.1111/j.1475-4959.2008.00315.x This article may be used for non-commercial purposes in accordance with Wiley Terms and Conditions for Self-Archiving.
}

\section{HOW TO CITE TSPACE ITEMS}

Always cite the published version, so the author(s) will receive recognition through services that track citation counts, e.g. Scopus. If you need to cite the page number of the TSpace version (original manuscript or accepted manuscript) because you cannot access the published version, then cite the TSpace version in addition to the published version using the permanent URI (handle) found on the record page. 


\title{
Does the Invisible Hand have a Green Thumb?
}

\section{Incentives, Linkages, and the Creation of Wealth out of Industrial \\ Waste in Victorian England}

\begin{abstract}
:
'Loop closing,' i.e., the creation of waste recycling linkages between different industries, has been hailed as a means of simultaneously achieving improved economic and environmental performance. As a result of the widespread assumption that traditional market incentives and institutions are not conducive to such an outcome, however, there remains a fair amount of skepticism as to what the capacity of business self-interest to promote this behaviour actually is. This essay challenges the dominant negative perspective by discussing by-product development in one of the most market-oriented societies in human history, Victorian England. Building on nineteenth and early twentieth century writings on the topic, as well as a more detailed analysis of the development of valuable by-products from highly problematic iron and coal gas production residuals, a case is made that the search for increased profitability within the context of private property rights often simultaneously promoted economic and environmental progress in the long run, as well as on different geographical scales.
\end{abstract}

Keywords: Victorian England, By-Product Development, Porter Hypothesis, Industrial Symbiosis, Coal gas, Coal tar, Slag. 


\title{
Does the Invisible Hand have a Green Thumb? Incentives, Linkages, and the Creation of Wealth out of Industrial Waste in Victorian England
}

\author{
"A leading feature of the Victorian epoch has been the utilisation of waste materials \\ and by-products." \\ - "Her Majesty's Jubilee - A Scientific Retrospect." The Chemical News LV, no. \\ 1440 (July 1 1887), p. 299.
}

\section{Introduction}

Many sustainable development theorists believe that pollution prevention measures systematically increase production costs, thereby inducing corporate managers to invest as little as possible effort in that respect. In the past few decades, however, several reports have documented innovations that, either through increased efficiency in resource use or in the development of valuable by-products out of production residuals, actually mitigated environmental harm while delivering economic benefits. Such 'win-win' cases have led to the emergence of a managerial philosophy that encourages industrialists to move beyond regulatory compliance of which the focus was on 'end of pipe' technologies, and emphasize instead constant waste elimination and pollution prevention. One branch of this literature that should be of special interest to geographers concerns the concept of 'industrial symbiosis,' i.e., by-product recovery linkages or 'loop closing' between diverse and (more or less) geographically proximate firms (Chertow 2000; Deutz and Gibbs 2004; Jacobsen and Anderberg 2004; Lyons 2007).

Considerable debate surrounds the 'greening' of industrial operations through such means with controversies ranging from whether relaxing regulations would entice managers and technicians to look for win-win solutions or to increase polluting emissions (Weber and Hemmelskam 2005) to the relevance of geographical proximity for loop-closing (Chertow 2000; Lyons 2007). While 
assessing the importance of the latter issue might seem relatively straightforward through case study analysis, generating insights into the former requires one to distinguish between the normal or exceptional character of win-win cases, and the respective roles of business self-interest, regulatory mandates, and popular pressures in generating such positive outcomes. One approach to addressing these questions is to look at the impact of market incentives on industrial behaviour in societies characterized by generally free-market policies, but where governmental regulations and general interest in protecting the environment are significantly weaker than in currently developed economies. As with some rising Asian economies today, these conditions are descriptive of Western societies during their early industrialization phase.

Since it came as close as any other past society in adhering to laissez-faire policies (Paul 1980), Victorian England will be used as a time- and geographically-circumscribed case study to provide a preliminary assessment of the 'spontaneous' propensity of entrepreneurs, managers and technicians to close the loop on their residuals, and the extent to which geographical proximity was an absolute prerequisite in the process. In other words, the aim of this paper will be to examine one aspect of the relationship formed between market institutions, industrial innovation and the environment over time, rather than to assess the specific environmental impact of production methods that were much cruder and more damageable than later ones.

The essay begins with a review of recent writings and available evidence on the topic. A sample of generally positive Victorian assessments follows, which are then supported and illustrated by more detailed case studies of the development of valuable by-products out of coal gas residuals (the various substances other than gas and coke produced in the destructive distillation of coal), 
and smelting furnace slag (the vitreous mass left as a residue by the smelting of metallic ore). The relative importance of business self-interest and external constraints in generating win-win outcomes and the diverse geographical scales at which they occurred are then addressed. Broader speculations for the development of institutions that might reconcile economic growth and environmental preservation/restoration are then finally discussed.

\section{Literature overview and methodological considerations}

Victorian England is usually associated with images of coal-powered mills, factories and mining operations that darkened the sky, polluted rivers and severely damaged the British countryside. This perception probably explains why only a few lines are devoted to the development of win-win innovations and industrial waste recycling linkages in some recent environmental histories of the period (Mosley 2001; Winter 1999). While various discussions of by-product development from industrial residuals have been written by historians of technology, the issue is typically treated peripherally in descriptions of advances made in the manufacture of principal products, while environmental improvements resulting from innovative practises are rarely touched upon (Haber 1969; Singer et al. 1954-1978). One exception is the book Chemistry, Society and Environment edited by Russell (2000: v), which attempts to provide the first "serious [historical] analysis of the [British chemical] industry's impact on the environment." While the contributors to this project discuss past cases of pollution in several industries, their focus is as much on the health of the workers as it is on the external impact of industrial activities and their treatment of byproduct development is often incidental. 
Perhaps the only recent historical work that specifically addresses the recovery of production residuals in Victorian England is B.W. Clapp's (1994) popular Environmental History of Britain since the Industrial Revolution in which three bold assertions are made: 1) a "long book would be needed to do justice to the economic history of byproducts" (p. 220); 2) which would tell "an untidy story, a mixture of success and failure, with no clearcut trend towards or away from full use of the byproducts available" (idem); 3) by-products were relatively more common in preindustrial economies than in later periods because they were derived primarily from living organisms. The author, however, provides no economic or technological rationales to support the last two of these claims, which are also contradicted in his own writings to a large extent. ${ }^{1} \mathrm{Be}$ that as it may, Clapp himself points out that the topic will always remain controversial, particularly since neither the population nor the production census was organized with the waste and by-product analyst in mind. In short, historical statistics on industrial residuals suffer from at least four major shortcomings: 1) they were often unaccounted for because they were used within the same firm; 2) the distinction between a primary output and a by-product is often arbitrary (should lard be considered a by-product?); 3) a former by-product might over time become the main output of a firm; 4) statistics often fail to convey important qualitative information. ${ }^{2}$

Much information on the topic can nonetheless be found in numerous contemporary books, monographs and articles (Desrochers 2007). Building on these and other sources, this essay will

1 Similar criticism could be addressed to Winter's (1999: 147) comment that, despite widely held beliefs that free markets rewarded innovation and punished waste, Victorian industrialists' interest in recycling waste "lagged behind developments in the relevant science and technology" unless "stimulated by protest or threat of regulating legislation."

2 For example, in the middle of the 19th century, large quantities of bones were imported in Great Britain, while many of the best British bones were simultaneously exported to France because of French workers' superior skills in turning chips and waste cuttings into small toys, ornaments and other profitable items (Bethnal Green Branch of the South Kensington Museum 1875). 
now document how Victorian institutions generated entrepreneurial outcomes that, at least in the long run, proved typically more sustainable than is now generally believed to have been the case.

\section{By-product development and loop closing in Victorian England}

\section{Contemporary assessments}

Many Victorian analysts considered that a considerable effort was directed at the development of by-products out of industrial residuals and that significant progress in this respect had been achieved over time in virtually all industries. This position can be illustrated with three seemingly unrelated quotes covering much of the time period in question. The first is from a contributor to the Chambers' Edinburgh Journal who wrote in 1851 that recent advances in chemical knowledge and "their extensive application to the useful arts" had created thousands of new jobs in "a variety of trades more or less curious in their character, but exceedingly important in their social effect" ('The Value of Rubbish' 1851: 122). It was indeed "gratifying to think that this employment is afforded, to a large extent, by the converting of commodities long regarded as worthless into articles of great commercial value and importance," although these trades "are not popularly known, if known at all, beyond the narrow limits of their immediate connection."

A generation later, a Vice-President of the British Society of Engineers, Perry Fairfax Nursey (1875: 401), commented that not too long ago "every department had what were termed its waste products." In some cases people were unaware of it, but in others manufacturers acutely conscious of their loss "strove in vain to lessen or prevent it." In time, however, advances in chemical and mechanical science had resulted in "the successful applications of waste substances in directions previously but little hoped for, if not wholly unthought of." 
Finally, another contributor to the Chambers' Journal observed at the end of the century that many industrial processes "necessarily throw off considerable quantities of refuse, the only thought with regard to which is, frequently, how best to get rid of it" ('Utilization of Waste Products' 1894: 591). If it was solid, the "increasing accumulations encumber the ground." If fluid, it was "most likely flowed - at least, until it was made illegal to discharge such matters into streams - into the nearest river or canal, polluting the water and destroying the fish; while waste gases and smoke vitiate and poison the atmosphere." It was nonetheless in dealing with these "unpromising materials" that "chemical and scientific skills have in some cases been remarkably successful, encouraging the hope that, in the future, much more may be accomplished in the same direction."

Some brief descriptions of the main advances in the creation of valuable by-products out of coal gas residuals and slag will now help convey a better understanding of the generally optimistic Victorian outlook on the question. These substances were originally selected for three reasons: 1) the significant environmental challenges they represented at one point in time; 2) to help provide a preliminary assessment of Clapp's (1994) statements that less by-products were developed from non-living organisms and that no clearly recognizable trend towards the full use of byproducts can be observed and; 3) to provide some indication as to the role of geographical proximity and interregional trade in the profitable recovery of bulky and seemingly low value residuals. 


\section{Coal Gas Residuals ${ }^{3}$}

'King coal' fueled the Victorian engine. While almost all of the United Kingdom's production was either consumed in industrial, transportation and domestic uses, or exported to other countries, a small percentage was heated with the addition of various amounts of steam and air in order to generate different varieties of lighting and fuel gas. ${ }^{4}$ Apart from the hydrogen-based gas (and excluding waste products generated from gas purifiers), ${ }^{5}$ coal gasification generated three residual substances. The first was a carbon-rich coke for which there was from the beginning a large demand to power engines and wherever a cheap smokeless fuel was needed, such as in railroad transportation. ${ }^{6}$ The second was dirty water rich in ammonia. The last, and by far most problematic, was a thick black viscous substance known as coal (or gas) tar. ${ }^{7}$

The first practical uses of coal gas were in English cotton mills beginning in 1805 and 1806, as well as street lighting in 1813 where its "brilliant lustre" provided a superior alternative to "miserable oil lamps" (Clegg 1841: 5). Its adoption in homes, however, was met with considerable resistance. Replacing tallow candles and oil lamps by air streaming through pipes was indeed quite a challenge because of the difficulties involved in removing a number of substances that were invariably mixed with it and, when burnt in a closed room, caused headache

3 This section deals with coal gasification for the explicit purpose of producing combustible gas and not with coke ovens operated for the production of harder coke for the metallurgical industries.

4 The percentage of UK coal production used for gasification was about $\%$ (approximately 1 million tons) in the early $1840 \mathrm{~s}$, between 5 and $6 \%$ in the late nineteenth century (about 9 million tons) and $3.5 \%$ (about 10 million tons) in 1913 (Church 1986: 23; Meldola 1905: 61-62).

5 The last residual of significance from coal gas production was the spent lime from purifiers. By the mid 1880s, however, a process for restoring the material "so that it can be used again and again" had proved successful (Newbigging 1887: 286). This spent lime also became an input in the manufacture of cement from furnace slag as discussed later in this essay.

6 The use of 'gas coke' was always more problematic than coke manufactured specifically for that purpose. According to Clegg (1841: 198), however, though not as long lasting and as free of slag, gas coke was nonetheless suitable for many purposes in the arts and manufactures, while its domestic use had always been "unobjectionable." 7 Coal gasification products varied greatly, both in terms of substance and volume, depending on the types of coal and technology used, with an increased quantity of gas obtained at the expense of its (and other residuals) quality. 
and sometimes respiratory problems (Clegg 1841: 13). According to Playfair (1852), the gas not only had an intolerably stale odor, but was noxious when burned, discoloured curtains, tarnished metals, ate through the covers of books, and covered everything with its fuming smoke. As Talbot (1920: 14-15) would later observe, early "cynics, critics, and caricaturists" lost no opportunity to suggest that the fumes released in rooms in which gas was burned caused a grave danger to the health and, in some cases, the lives of the occupants.

Just as problematic was the "dolefully foetid and repulsive" gas water ('Penny Wisdom' 1852: 98) and, even more importantly, the "uninviting, ill-smelling, black sticky" (Baekeland 1914: 181) residual tar whose "soiling powers" were "unequalled" and odor "unapproachable," making it one of the "most repulsive nuisances known to manufacturers" ('Review' 1868: 345). When discharged into streams and rivers, coal tar floated in "ghastly blue patches" known as "Blue Billy" and killed all aquatic life (idem). When buried, it destroyed the surrounding vegetation (Playfair 1892). If burned, it generated a heavy black smoke that poisoned the atmosphere over large distances (Crookes 1862). Not surprisingly, early coal tar disposal practices generated numerous complaints and costly litigation procedures for gas companies and reckless disposal practices were soon prohibited. Indeed, despite an initially limited and very polluting use as a fuel in gas plants, gas producers were more than willing to give it away for free to anyone who would cart it away (Meldola 1905: 68-69) and coal tar remained a nuisance for more than a generation after the first introduction of gas-lighting (Lunge 1887: 11).

Coal gas residuals quickly became the "bane of life" of early gas engineers, "harassing them to the verge of endurance," with their elimination soon commanding "the expenditure of enormous 
sums of money and prodigious thought” (Talbot 1920: 15). Despite initial failures (Clegg 1841; Russell 2000), hundreds of remunerative by-products derived from these substances would eventually become the original building blocks of our modern synthetic world, with coal tar eventually described as the "queen of the by-products of many manufactures" ("Utilization of Coal Waste' 1876: 159), "a storehouse of wealth and beauty" (Wright 1886: 558) and the "flower of the chemical industries" (Green 1902: 7). As one commentator pointed out, in time numerous factories sprung up to create valuable by-products out of gas tar and ammoniacal liquor, in the process, "as if by magic," elevating them "into materials which appeal to the sense of beauty and delicacy in every form” ('Utilization of Coal Waste' 1876: 159). As Talbot (1920: 15) further observed while pondering the advent of electrification, the gas generated from the destructive distillation of coal had by then become for all intents and purposes a by-product without which "the world could roll along very comfortably" as all the real value extracted by this process then came from former production residuals. Such developments, however, had required tremendous entrepreneurial and developmental initiative. What follows is a short description of the main advances in this respect.

Apart from early and often problematic uses as a protective coating for the hull of wooden ships and ropes, fuel and for roofing, the first highly significant demand for coal tar followed the introduction of the wood pressure-impregnation process in 1838 (also known as the Bethell, full cell or vacuum-pressure process) by John Bethell (1804-1867) of Greenwich. This 'pickling' or 'creosoting' of timber - a process through which dried timber was placed in a container, subjected to partial vacuum and impregnated with heavy oils from coal tar - soon thrived on a large scale as a result of the increasing demand for wooden sleepers by the railroad industry, of 
wooden poles by the telegraph industry and of various coastal structures which incorporated a significant amount of timber. Interestingly, Bethell began to experiment with tar oil upon learning about ancient Egyptian mummification techniques and originally had to contend with widespread prejudice against anything smelling of gas (Calvert 1855). This industry not only "saved the situation" as far as tar disposal was concerned, but also significantly reduced both the cost of maintaining wood structures and, by tripling or quadrupling its useful life, the consumption of wood (Findlay 1917: 26-29). In later decades, creosote would become an important British export item, especially for the burgeoning American railroad industry, while numerous improvements upon and alternatives to the Bethell process were developed (Richardson 1993). Of course, creosoting also created unforeseen problems (Krook et al. 2006), but it seems fair to say that these were less important than those solved in the first place.

The most significant Victorian creosoting firm was Burt, Boulton and Haywood (BBH) which was active in numerous British and foreign locations. ${ }^{8}$ By the mid 1870 s, timber imported from various Baltic ports was turned annually into approximately $1,500,000$ creosoted railway sleepers in its East London operations and then shipped to destinations as remote as India (Crory 1876: 27). Around 12,000,000 gallons of gas tar were required to achieve this result, a quantity similar to that produced yearly in London at the time. Of course, as other London firms also consumed significant amounts of coal tar, BBH managers imported large quantities of this residual from other parts of England. As Crory (1876: 31) observed, this manufacture was not only a vivid illustration of the well-known admonition to "gather up the fragments that remain,

8 Founded in 1848, BBH is now a division of the Finnforest group company that markets itself as "the longest established timber preservation company in the world" http:/www.bbhpreservingwood.co.uk/. 
that nothing be lost," but also increased the dividends on gas company shares, reduced the price of gas for consumers, and created several skilled and unskilled jobs.

Other uses for tar creosote (or carbolic acid) were eventually developed. The most prominent was its large scale use in the preparation of cattle washes, sheep dips, and general disinfectants. It was also used as a fuel in diesel engines and for lighting, in the production of lamp-black, for softening or 'revivifying' hard pitch (the hard black residue left once the liquid fractions had been removed from the coal tar), and for scrubbing coal and coke-oven gas for the recovery of benzene and toluene. The heavier liquid fractions of coal tar found further outlets in the preservation of iron, bricks and stone, in the preparation of roofing felt and, when produced in isolated plants where they could not be recovered economically for further processing, burnt more cleanly and efficiently than before (Wright 1886; Stansfield and Carter 1915).

No comparable markets, however, originally existed for the remaining lighter fractions of tar oil, which, while much less significant in terms of volume, proved too volatile for civil engineering applications. Early users of the Bethell process converted the light fractions as "coal-tar naphta" for burning and dissolving rubber and gutta percha ${ }^{9}$, and for a few additional uses (Lunge 1887: 11). These applications, however, resulted in only a limited demand for a product which was rapidly increasing in supply. As a result, the lighter fractions were originally "in much about the same industrial position as the tar itself before its application as a timber preservative" (Meldola 1905: 71).

9 A rubbery substance derived from the latex of several tropical trees whose uses over time included electrical insulator, waterproofing compound, and golf balls. 
The "day of light tar-oils" (Lunge 1887: 12) would eventually come on the heels of chemical advances that allowed the preparation of benzene and nitrobenzene on an industrial scale. Among early uses for this substance was, in the latter case, as a substitute for the essential oil of bitter almonds (a colouring and perfuming agent). Beginning with William Henry Perkin's (1838-1907) (at the time based in East London) mauve in 1856, the synthetic dyes industry soon provided significant markets for these previously useless residues. Actually, this industry's reliance and willingness to pay for a growing number of coal tar derivatives ensured that "the other products of tar-distilling could be sold at low rates and new markets could be opened out for them" (Lunge 1887: 12). In time, advances in synthetic dye making served as a technological springboard for the creation of other tar-derived products ranging from explosives, medicines and perfumes, to flavoring materials, sweeteners, disinfectants and antitoxins, as well as tracing and photographic agents. As a commentator observed in the early years of these developments, it seemed "almost incredible that delicate tones of colour" and the "most delicious flavours" should be derived from "so foul a source; but so it is" ('Utilization of Coal Waste' 1876: 159). While examining the details of the developmental work, environmental benefits and (typically unknown at the time) more problematic aspect of these activities is beyond the scope of this paper, suffice it to say that the replacement of various dyeing substances extracted from plants (principally madder and indigo), lichens, trees, insects, mollusks, minerals and guano by synthetic dyes simultaneously reduced extractive pressures while allowing increased food production - and eventually reforestation in several locations (Findlay 1917; Meldola 1905; Travis 1993).

In the meantime, English domestic and industrial demand shifted increasingly towards gas of increased calorific value for use in industrial processes, cookers and illumination with new 
incandescent mantles whose preparation resulted in smaller volumes of by-products. During the late Victorian period, leadership in chemistry-based industries was increasingly taken over by German firms. As a result, an elaborate international trade in coal and its derivatives emerged through which colliers with English gas coal bound for North Africa and Europe returned home carrying crude coal tar, which was then fractioned to various degrees and exported to Germany. Indeed, as late as 1908, German imports of British coal tar and derivatives (including dye intermediates) would hover around 40,000 tons a year (Findlay 1917).

Valuable products ranging from substitute asphalt, black varnish, and hard pavements to disinfectants, roofing-felt and electrical insulation, were with time also manufactured in part from the residual hard "pitch" (Findlay 1917). One of its most successful markets was created in 1832 by French entrepreneurs Ferrand and Marsais, who mixed it with coal-dust formerly wasted in mining operations, in the process producing a commercially successful 'patent fuel' of which between two and three million tons were manufactured annually in the UK and continental Europe by the end of the nineteenth century (Meldola 1905). The road to 'patent fuel,' however, had been an arduous one, for the expression reflected several unsuccessful attempts made from at least the seventeenth century onwards to utilise waste materials, such as coal dust in the UK and charcoal and saw dust (mostly) in Northern Europe. Indeed, if the number of patents taken to that effect had been sufficient "to induce the manufacture of any article in proportionate quantities," the amount of residual coal dust and fragment would have been significantly less than was actually the case ('Patent Fuel' 1872: 161). ${ }^{10}$

10 Coal tar was originally used in the manufacture of patent fuel, but pitch eventually proved a more attractive alternative. Crookes and Röhrig (1870), Hunt (1867) and Lunge (1887) are concise descriptions of the main manufacturing processes used at the time. Perhaps as much as a third of coal was wasted in the form of "small," 
The production of patent fuel in the UK was originally concentrated in South Wales (Cardiff and Swansea), with initial demand chiefly concentrated in the transportation (mostly shipping) sector. Interestingly, the UK patent fuel industry lagged between that of countries such as Belgium and France. Good artificial fuels made from coal dust were nonetheless said to have a number of advantages, ranging from greater efficiency in handling, storage and steam generation, to much lower emissions of clinkers, smoke and ashes (Crookes and Röhrig 1870; Lunge 1887). According to one commentator, legislative mandates to curtail smoke emissions from locomotives originally facilitated the sale of this product, as the supply of gas coke was at one point in time insufficient and more expensive than patent fuel. As a result, railway companies obtained their coke more cheaply than was formerly the case, coal owners made "something out of a (commercial) nothing" and the land surrounding some coal pits became increasingly "freed from an incumbrance” ('Penny Wisdom' 1852: 99).

The ammonia rich residual water formerly "carried off by covered drains as a nuisance" ('Nothing is Useless' 1849: 19) similarly became the basic input of valuable goods such as carbonate of ammonia (produced with the addition of quicklime); sal-ammoniac (produced with the addition of a strong acid, such as hydrochloric acid - itself a residual of alkali production); and sulphate of ammonia (through the addition of sulphuric acid), all valuable inputs in industries ranging from pharmaceuticals and dyeing to printing and fertilisers (Crookes 1862). While the purging of ammonia was done for "sanitary reasons" as well as "to meet wise

\footnotetext{
“slack," or "duff” in the 1870s ('Patent Fuel” 1872). 'Coke-breeze' was also used in this manufacture.
} 
legislative demands," it was typically in the corporate interest to act in this manner as all ammoniacal products were "easily sold" and brought a "fair price" (Crory 1876: 38).

Finally, the refuse of combustion, such as clinker, soot and ashes, proved valuable in the preparation of mortar, roads and manure (Simmonds 1862: 412-415).

While distant markets and sources of supply were often prerequisites to ensure the commercial viability of some of the operations described in the previous paragraphs, geographical proximity, as can be expected, often played a significant role in this respect. Among the various locations where this could be observed was Bow Common (London) where a 'Gas Products Utilising Company' was supplied by and then shipped some of its by-products back to the adjacent 'Great Central Gas Company'. In order to work up the "sal ammoniac" produced by the former, another chemical firm eventually built an adjoining factory ('Review' 1868: 346-347). A few years later, during the opening of the South Metropolitan Gas Company of London, guests were allowed to visit a nearby large chemical plant specifically built for working up the gas tar of the adjacent gas works ('By Products of Gas Making' 1884: 276). In the late nineteenth century, several east London plants were processing tar and pitch obtained from nearby coal gasification plants because crude tar, along with the resulting remunerative by-products, could be delivered cheaply and exported conveniently by barge from this location to the Continent.

In the end, it could be said that the "magic wand" of chemistry had touched "the most noisome substances" and turned them into "the most ethereal essences, the most heavenly hues [and] the most delicate flavours and odors" ('Utilization of Coal Waste' 1876: 159). Indeed, by the early 
1880 s, a reputable chemist would startle London's gas consumers by announcing that the cost of manufacturing gas "was fully defrayed by the sale of the by-products" ('By Products of Gas Making' 1884: 276). According to another source, at that time English gas companies derived approximately 30 per cent of their revenues from residual products (Price 1886: 464).

Since creative destruction is the foundation of market economies, illuminating gas would eventually be displaced by electricity, ${ }^{11}$ fuel gas by natural gas (which, consisting essentially of methane, had a much higher heating value) and hundreds of tar-based derivatives by natural gas and former residues of petroleum refining.

Although the sheer scope of by-product development in the coal gas industry may have been without parallel in the Victorian age, it was not fundamentally unique, as will now be illustrated by a brief overview of the development of valuable goods from slag.

Slag

"Of all the waste substance for which modern science has found a practical use," one late nineteenth century observer wrote, "none could well seem more hopeless than the slag from blast furnaces employed in the smelting of iron," for this "bete noire of the furnace proprietors" which was floating on top of the iron ore because its lighter weight was a residual "even more unpromising than the "tar' of the gas manufactories" which had been so often "cited as a striking instance of the utilization of a waste product long regarded as a nuisance, to be got rid of only with much labor and expense” ('Utilization of Blast-Furnace Slag' 1880: 624). 
Throughout the Victorian era, the yield of blast furnace slag represented roughly half as much as that of the iron produced while its bulk was more than three times greater than that of the metal. It was until the last three decades of the nineteenth century one of the most expensive, cumbersome and useless residuals known to industrialists (Nursey 1875: 401). This is not to say that no remunerative use whatsoever existed up to this point, as some quantities became 'road metal $^{12}$ and a flux to the copper ore in smelting operations. For the former use, the whole of the slag produced in Northamptonshire and in certain districts of Yorkshire was for a while sold at a fair profit, but these were local exceptions (Lock 1884). ${ }^{13}$ Regarding the latter, some slag was shipped from the principal ports of the United Kingdom to what was then the main seat of copper smelting, Swansea ('The Value of Rubbish' 1851).

Road making and copper smelting, however, only used a small portion of the increasingly large quantities of slag produced in the United Kingdom at the time. Iron manufacturers had therefore no choice but to purchase large tracts of land to dispose of it; an investment that was not only "wholly unremunerative," but also necessitated an amount of labour comparable to blast furnace operations (Nursey 1875: 401). As one writer put it, hundreds of acres of land in the iron districts of Great Britain had been to be used for this purpose, in some localities "the iron-masters [had] been at their wits' end to find more room for the purpose" and, in most cases, "the slag has been an elephant on the hands of the manufacturers, bulky and costly to dispose of" ('Utilization of

12 The original English meaning of "metal" referred to anything useful that had been extracted from the ground, including sand, clay, rock and earthen matter in general. Near the end of the eighteenth century, the word began to be used for the crushed rock that were one of the main components of the road surface system pioneered by the Scottish engineer John McAdam.

13 Greater use of slag as road making material could then be observed in continental locations such as Silesia where stone was scarce (Nursey 1875; Simmonds 1883). 
Blast-Furnace Slag' 1880: 624). Simmonds (1876: 460) conveys in graphic terms the plight of metallurgical districts "where undying flames leap forth from hundreds of volcanoes" and around which "nothing is discoverable but blackened piles of cinders and unsightly slag":

For scores and scores of miles, the traveller beholds these apparently interminable heaps of refuse ore. Carts, wagons, and trucks may be seen on all sides, occupied in the endless task of removing this metallic encumbrance of the smelting works. Hundreds of labourers are engaged in conveying to remote and undisturbed spots the enormous piles of black, friable, clinkery-looking stuff... Some is flung down deep gullies, and hidden in the dark yawning recesses of ravines, when haply any such are to be found. Some is employed in the hardening of rotten roadways, where it is made to perform a very unsatisfactory sort of duty for stone. Occasionally it is shot into the sea, when near enough for that purpose, which, however, is not often the case (idem).

Of course, it was obvious to everyone that if "any use could be made of this waste, the profit to the iron-master would be great; for, independently of the room it takes up, the cost of removing it is [expensive]" ('Review' 1868: 351) According to Simmonds (1876: 461), in the early 1870s, fully six million tons of slag were produced annually in England, and not much less than half a million sterling was expended to get rid of it,,${ }^{14}$ the total quantity of which had probably reached eight millions tons per year by the end of the decade ('Blast Furnace Slag' 1879; Lock 1884; Simmonds 1883). At Barrow-in-Furness, about 19 million tons had been produced in the previous two decades, which amounted to roughly enough to have built six Cheops-sized

14 According to MeasuringWorth.com, in 2005, $£ 500000$ from 1870 was worth almost $£ 32$ million using the retail price index. 
pyramids. Some of it had been used for land reclamation from the sea, for filling up sunken lots, for the building of sea walls, embankments and similar projects to improve navigation (Nursey 1875; Simmonds 1876; 'Utilization of Blast-Furnace Slag' 1880). In the Black Country, some walls and houses had been erected out of moulded slag blocks and had, in some instances, "a very pleasing appearance, owing to the variegated nature of the slag" (Nursey 1875: 402). Another commentator, however, described the "indestructible" walls built of slabs in the vicinity of iron foundries as "too ugly in appearance, being rough and black, to gain the attention of architects” ('Review' 1868: 352). Such uses, however, were clearly insufficient. For example, the construction of breakwater, training walls and other structures on the Tees annually consumed only about 600000 tons of slag, while in the Cleveland district alone, between three and four million tons of slag was produced each year ('Reports of Engineering Societies' 1879b; Mason 1879; Simmonds 1883).

Nevertheless, slag had much potential, for it was a material that, when fluid, could take almost any shape and, when solid, remain unaffected by fire ('The Utilisation of Slag' 1873: 170). In the words of Lock (1884: 430), here was "a material flowing to waste, in a liquid state, capable of being run into moulds, and of taking impressions almost equal to those of cast-iron" and whose resulting successful castings were not only exceedingly durable, but also "even beautiful to look at." Its main challenges, however, were its brittleness; the typically lower cost of substitutes such as paving stone and clay bricks; and high transportation costs ('The Utilisation of Slag'; Lock 1884; Nursey 1875; Simmonds 1883). Not surprisingly, "from the first persistent efforts have been made either to utilize [slag] or to get rid of it altogether" and the "variety of schemes proposed for either or both of these purposes has only been equalled by the ingenuity displayed 
in devising them" (Nursey 1875: 401). For casting slag alone, from the early 1830s onward, at least one new patent a year was filed by inventors who thought they had devised a commercially successful way of creating marketable products of this waste product (Lock 1884).

For instance, on the evening of March 25, 1855, a Dr. William Smith of Philadelphia read a paper at a London meeting of the Society of Arts on "The Utilization of the Molten Mineral Products of Smelting Furnaces" in which he discussed a new technology that he had developed to turn slag into bricks or blocks for use by the construction industry. In the following question period, one Mr. Nesbit observed that the subject at hand was not a new one, for he had himself published numerous works on the topic in Southern France, South Wales, and parts of England and Scotland, almost a decade earlier ('The Utilisation' 1855: 340). Other participants commented on the high disposal cost of this waste material, and on the fact that it could, when this was the case, be obtained very cheaply from producers. One Mr. Austin pointed out that some iron masters paid as much as $3 \mathrm{~s}$. $6 \mathrm{~d}$. per ton $^{15}$ to remove the slag; a circumstance that significantly increased the price of iron. Finding some useful purposes for this residual matter would therefore be beneficial on several counts. Achieving this result, he argued, "only required the spirit and energy which Englishmen possessed" (idem: 341).

By 1873 , nearly 60 different systems designed to create commercial commodities from slag had been patented or tried on a significant scale, but none of these experiments proved successful, despite sometimes enormous expenditure of time and money (Wood 1877). As commentators put it, "seemingly endless experiments [had been] attended by apparently endless failure" (Nursey 
1875: 402) which owed "either to the difficulty of dealing with [slag] or to the attendant expenses" (Mason 1879: 106).

The first entrepreneur/inventor to achieve significant success in this respect was Charles Wood of Middlesbrough-on-Tees, who devoted about five years of study, experiment, and applied research to the issue (Mason 1879: 106). Wood's breakthrough was his discovery that melted slag runs from blast furnaces fell into a fine granulated state, in the process removing the significant cost associated with its grinding ('Hydraulic Cement' 1885: 85). ${ }^{16}$ In 1877, his Cleveland Slag Works (whose main structure was built of concrete made of slag sand) had successfully turned local slag into nearly a dozen different classes of lucrative goods. Wood (1877: 247) described the developmental tasks as having been "severe:"

When I designed the mill, I brought to my assistance some of the most experienced millwrights in England - men accustomed to machinery for manipulating hard and gritty substances; and yet there is scarcely a piece of machinery on the works with the exception of the engine and shafting that has not either been abandoned, redesigned, or rebuilt, in order to adapt the machines to this peculiar material, the extraordinary cutting nature of which seemed to destroy everything with which it came into contact. In proof of this, I may mention two facts, viz., that in six hours' working, the fields and furrows, in a pair of French burr millstones, intended for

16 Some of these experiments and their financial backers, results, manufacturing processes and commercial products, along with the specific characteristics of the slag found at this and other locations, are described in 'Adulterated Cement' (1872), 'Blast Furnace Slag' (1879), 'Reports of Engineering Societies' (1879), 'Utilization of Blast-Furnace Slag' (1880), 'Utilization of Wastes' (1880), 'Hydraulic Cement' (1885), Lock (1884), Mason (1879), Nursey (1875), Wood (1877) and Simmonds (1883). 
Portland cement grinding, were completely obliterated, whilst the hardest steel bars in a Carr's disintegrator were cut completely through after six or eight days' constant running. The position of an engineer and an inventor under these circumstances standing as he does between failing machinery and the angry directors of a limited company, in times like these - is one which has only to be experienced to be thoroughly appreciated (idem).

Of course, Wood's success had been achieved with the support of local iron producers and "the good wishes of all” (Reid 1881: 94). Among his main backers were Messrs. Gilkes, Wilson Pease and Co., whose adjacent Tees Iron Works were originally managed by Wood and later became his main slag supplier (Mason 1879: 107). Other pioneers singled out at the time include one Mr. Bodmer of the Spring Vale Brickworks (Hammersmith) who, building on Wood's process, developed other construction products (Nursey 1875; Mason 1879). Another was Bashley Britten of Northamptonshire, who established the large scale manufacture of slag-based coloured glass - especially bottles said to be "superior for strength to those of common flint glass" ('Utilization of Wastes' 1880: 36) - and whose works were situated next to the Finedon Iron Works blast furnaces from which the molten slag was conveyed by carriers (Mason 1879; Lock 1884).

Another was Frederick Ransome who had reportedly developed a white cement of greater strength than Portland cement by reducing Wood's slag sand into a fine powder, mixing it with chalk or limestone, and burning the resulting mixture to a moderate heat (Mason 1879: 110), a process judged a few years later as "deserving of being ranked as one of the most important of 
recent years in the arts to which it relates" ('Hydraulic Cement' 1885: 85). Among later improvements, Ransome found that using the spent lime of gas work purifiers as a substitute to lime prepared specifically for that purpose gave similarly good results (idem; Newbigging 1887: 286).

To summarize, the earliest profitable manufacturing uses of iron-smelting slag included being cast into building blocks; granulated to make building sand; made into cement, concrete, mortar and bricks; mixed with chemicals to be turned into the commoner grades of glass; and blown by steam jets into filaments to make mineral wool (then often labelled 'silicate cotton' or 'slag wool' for its resemblance to cotton-wool) to cover boilers, steam pipes, and other contraptions. By the late 1870 s, approximately three million slag bricks were produced annually by Wood and other manufacturers in the Middlesbrough area. Most of these bricks were shipped to London where they were largely used for interior work because of their toughness, while some of their other products were used for paving streets and crossings in several towns of northern England ('Blast Furnace Slag' 1879; Mason 1879). Wood's mineral wool was similarly shipped to the London firm of Messrs. Daniel Dade and Co., where it was made into layers designed to prevent the loss of radiant heat on steam boilers and other machines (Mason 1879: 109). Apart from the manufacture of artificial stone, slag was also moulded into chimney-pieces, window-heads, balustrading, and various outside ornaments to be used by builders (Mason 1879; Simmonds 1883). According to Perry (1908: 48), slag-derived products greatly benefited the construction trade by lessening the "cost of building for those who desire simple but comfortable homes," while greatly enriching "the concerns which have had enterprise enough to make such wise use of a vast refuse heap." 
Building on earlier research ('The Utilisation of Slag' 1873), chemists further discovered in the 1880s that the ammonia and phosphorus contained in the slag derived from phosphoric iron ores made an excellent fertilizer when grounded up and proved more effective than lime in sweetening the acid soils of rain-soaked Britain and other locations (Clapp 1994; Lock 1884). A pioneer in this respect was one P.G. Thomas, a London police-court clerk who had studied chemistry at night school and learned that whoever could successfully use phosphorous ores in the-then recently developed Bessemer process would make a fortune (Gale 1996/1990). Among later developments related to the phosphorous-rich slag produced in the puddling furnaces of South Staffordshire, was a German chemist's discovery that it could be a valuable input in the production of basic steel, in the process transforming it from a "less than worthless" material into a lucrative item that was soon exported in large quantities ('Utilisation of Waste Products' 1894: 592).

Slag also became an important input component of many new types of road-making materials. The widespread paving of British roads in the early twentieth century and later road construction (which also used large amounts of coal tar) would, in turn, result in significant landscape improvements. ${ }^{17}$ As Kershaw (1928: 3-4) observed, this line of work not only provided a market for newly produced slag, but also for the gigantic past accumulations of this material, in the process gradually improving the "outward aspect" of the Black Country.18

17 Andersson-Sköld et al. (2007) is a recent discussion of environmental problems related to coal-tar asphalt. 18 "Old" slag could be used just as well as fresh molten slag, but its loading and crushing costs were higher. 
Synthesis on Available Case Evidence

While generalizations derived from case studies are always problematic, the research undertaken in the preparation of this essay suggests that the fate of coal tar residuals and iron-smelting slag was typical of manufacturing outcomes during the Victorian era. Indeed, as the journalist and publisher Peter Lund Simmonds (1862: v) wrote in the introduction of his 420 page Waste Products and Undeveloped Substances, the satisfactory treatment of the subject for any branch of manufacture "would of itself form a useful and interesting volume."

To answer the questions raised at the beginning of this section, much evidence suggests the following: 1) significant environmental challenges were successfully and profitably tackled over time in market-oriented Victorian England; 2) there are no economic or technological reasons to believe that fewer by-products were developed from non-living organisms than from living organisms and there seems to be a significant trend towards the full use of the residuals then available; and 3) while geographical proximity was sometimes crucial to the economic success of recovery operations, more distant suppliers and markets were also significant. On this last point, the fact that commodities as bulky as slag and potentially toxic as coal tar were once, in either a raw or semi-transformed state, significant export items further suggests that loop-closing was, is and will always take place at different geographical scales. In some cases, as in the adjoining operations characteristics of early slag by-product developments, geographical proximity will prove valuable by reducing drastically transportation costs. In others, such as the early German chemical industry, localized concentrations of human skills and large-scale operations are able to compensate for the friction of distance by providing a setting in which more valuable inputs can be created out of residuals produced in distant locations. In this 
context, it is probably the case that market prices convey reasonably well the trade-offs between the energetic requirements of transportation and the additional value created through the longdistance trade of residuals.

As will now be argued, apart from a profound dislike of waste that is probably characteristics of most technically creative people, two main types of market incentives were invoked to explain the outcomes described in the previous sections. The first, and probably most important, was the search for increased (or at least constant) profitability. The second was the necessity of removing nuisances to other parties that could result, either through common or statutory law, in significant penalties and even the shutting down of manufacturing operations.

\section{Incentives, institutions and loop closing}

\section{Competitive pressures}

Because of the profit motive, industrialists always had an incentive to pass as much of their costly inputs through the economy as possible rather than to release a fraction of them as pure losses in the air, water or on the ground. As an anonymous writer observed at the time: "In many trades the by-products alone give the profit, in these days of keen competition, and the abler the chemists who presides in such establishments, the more these by-products are likely to be remunerative” ('Review' 1868: 347). A similar diagnostic was provided by Nursey (1875: 401) when he wrote that the term 'waste products' had, by common consent, "now all but expunged from the vocabulary of applied science" and been replaced by 'bye-products,' an expression "so pregnant with meaning." Indeed, "manufacturers, instead of seeking how best to rid themselves of what they in their ignorance deemed a nuisance and an incumbrance, are now for the most part 
busied in devising methods for its careful retention, with the view to its ultimate conversion into substantial profits" (idem).

\section{Removing Nuisance}

While owners, managers, workers and merchants whose income ultimately derived from industrial activities may have been inclined to view polluting emissions as a reasonable price to be paid for the benefits generated by economic development, it would be a mistake to assume that no legal actions were taken against polluters in the Victorian age. In short, the institutional structure of a market economy is not only based on price signals and the resulting profits and losses, but also on private property rights and the rule of law. In this context, any substantial and unreasonable interference with the use and enjoyment of private property resulting from neighbouring manufacturing activities is no more acceptable than vandalism. Numerous Victorians whose health and property suffered from noxious emissions therefore took legal actions based on the common law doctrines of negligence, trespass, nuisance and strict liability for abnormally dangerous conditions and activities. Such a liability system mandated no specific conduct, but allowed private parties to recover monetary damages for harm caused, and even to gain an injunction against offenders that could ultimately result in a polluter's obligation to shut down its operation until problematic emissions had been addressed satisfactorily (Brubaker 1995; Meiners and Morriss 2000).

In addition to the traditional common law approach, specific regulations were eventually introduced for the stated objective of dealing with types of pollution that could not be easily handled through property rights. But whether through common or statutory law, the chemical 
engineer J. B. C. Kershaw (1928: 2) observed that the treatment of industrial wastes was often dictated by the necessity of "converting into an innocuous form some waste material, either solid, liquid, or gaseous, which, in its untreated state, is objectionable to the eyes or nose, or is detrimental to the health of the community." He added that under such circumstances, profitability was "entirely secondary in importance." For example, in BBH operations in East London, a seventy feet long iron vessel had been built to collect and store pitch until all the vapours were condensed, in order to be able to run it "without the possibility of its creating a nuisance," a mechanism that had "evidently been carried out with great care and skill, and at a very heavy expenditure" (Crory 1876: 30)

Somewhat surprisingly in light of current theoretical debates, a number of writers at the time observed that private property rights and environmental regulations sometimes triggered creative thoughts among manufacturers which in turn, eventually resulted in the creation of profitable byproducts from industrial residuals (Desrochers forthcoming). In doing so, they anticipated by more than a century the so-called 'Porter Hypothesis' according to which well-designed regulations can stimulate innovations that, by enhancing productivity and reducing waste, increase private and social benefits (Porter 1991). In light of the number of authors who independently made the argument, it seems reasonable to assume that private property rights and statutory laws occasionally triggered research efforts that eventually resulted in win-win outcomes. Most writers at the time, however, emphasized the role of competitive pressures in this respect (Desrochers forthcoming). 
Assuming that the previous analysis of industrial behaviour in the context of a market economy is reasonably accurate, a broader discussion on the role of market incentives and institutions in the development of more sustainable industrial practises can now be tentatively offered.

\section{Speculations on innovation policy and sustainable industrial development}

Calls for a fundamental rethinking of current business practises, along with the perceived necessity of new ethical considerations and ever more stringent environmental regulations, are now ubiquitous. Much historical evidence, such as the case of Victorian England, nonetheless suggests that the outcome of market forces was more positive than is commonly believed overall.

First, the search for increased profitability in the context of properly defined and enforced private property rights does not seem to systematically result in an unmanageable trade-off between 'business as usual' and environmental protection - although, of course, open access situations or price-distorting subsidies will typically generate more problematic outcomes than would be the case in their absence. While discarding residuals in the environment might allow some manufacturers to lower production costs in the short run, this strategy is obviously never as desirable from a strictly economic perspective as creating value out of them. Institutional contexts characterized by intense competitive pressures would therefore seem more likely to generate environmentally desirable outcomes through the creative elimination of wasteful behaviours and emissions. Assuming this premise to be correct, it would logically follow that increased competition should be promoted through freer trade rather than the breaking up of successful large firms whose size reflects a more efficient handling of their inputs than their 
competitors. Freer trade would therefore not, as is commonly believed, create an 'environmental race to the bottom' between competing jurisdictions, but rather the opposite.

Second, there is some evidence to support the notion that legal sanctions (or their threat) have the additional benefit of focusing the minds of manufacturers on pressing problems. Unlike many provisions currently found in the modern 'command-and-control' environmental regulatory apparatus, however, the common law did not mandate a specific technology to deal with particular problems, and did not establish an arbitrary distinction between a useful material and a waste which often prevents their profitable reuse (Desrochers 2002; forthcoming).

\section{Conclusion}

Despite what seems to be a widespread belief as to the inherent incompatibility of profit-making activities and sustainable development, much evidence suggests that the rational interest of business, at least insofar as the development of by-products from industrial waste is concerned, has perhaps never been diametrically opposed to the environmental interest of society. Indeed, market institutions such as those found in Victorian England seemed to have proven effective at focusing manufacturers' developmental efforts on technologies that produced long-term economic and environmental benefits. This is not to say, of course, that Victorian firms were more efficient or cleaner than current operations whose foundations are built on more than a century of subsequent technical innovations and scientific discoveries, but simply that industrial waste recovery or by-product development is a 'spontaneous,' if never perfect, outcome of market institutions. 
If this was the case, however, why is this not widely acknowledged today? One can think of a few reasons, ranging from a widespread misunderstanding of the effect of prices and competition on industrial behaviour to a natural propensity among news and activist organizations to draw attention to a minority of reprehensible manufacturing operations and presenting them as illustrative of widespread practises. Perhaps more importantly, however, is the difficulty for most individuals to understand that economic development spontaneously decouples the 'natural' and 'economic' spheres by closing the loop on industrial waste, therefore allowing the creation of increased wealth, while progressively diminishing the environmental impact of industrial activities. Be that as it may, a more nuanced analysis of the environmental consequences of business self-interest in the context of market economies is probably long overdue.

\section{References}

Adulterated Cement, 1872, The Manufacturer and Builder, vol. 4, no. 2, pp. 42.

Andersson-Sköld, Y., Andersson, K., Lind, B., Claesson, A., Larsson, L., Suer, P., and Jacobson T. 2007, 'Coal Tar-Containing Asphalt: Resource or Hazardous Waste?', Journal of Industrial Ecology, vol. 11, no. 4, pp. 99-116.

Ayres, R. U. and Ayres, L. U. 2002, A Handbook of Industrial Ecology, Cheltenham, Edward Elgar Publishing.

Babbage, C. 1832, 'On the Economy of Machinery and Manufacture', Charles Knight, London, Pall Mall East, [Online] Available at:

http://www.socsci.mcmaster.ca/ econ/ugcm/3113/babbage/, Accessed 10 February 2008.

Baekeland, L. H. 1914, 'Some Aspects of Industrial Chemistry', Science New Series, vol. 40, no. 1023 , pp. 179-198.

Bethnal Green Branch of the South Kensington Museum 1875 Descriptive catalogue of the collection illustrating the utilization of waste products George E. Eyre and William Spottiswoode for Her Majesty's Stationery Office, London

Blast-Furnace Slag, 1879, Van Nostrand's Eclectic Engineering Magazine, vol. 21, pp. 497-501. 
Brubaker, E. 1995, Property Rights in the Defence of Nature, Earthscan Publications Limited, Toronto.

By Products of Gas Making, 1884, The Druggist, 15 December, vol. VI, no. 12, pp. 276.

Calvert, F. 1855, On the Manufacture and Applications of Various Products Obtained from Coal (Coal-Gas Excepted), The Mining Magazine, vol. 4, pp. 28-32.

Chertow, M. 2000, Industrial Symbiosis: Literature and Taxonomy, Annual Review of Energy and the Environment, vol. 25, pp. 313-37.

Church, R. 1986, The History of the British Coal Industry, Volume 3: 1830-1913, Victorian PreEminence Clarendon Press, Oxford.

Clapp, B. W. 1994, An Environmental History of Britain Since the Industrial Revolution, Longman, London.

Clegg, S. 1841, A Practical Treatise on the Manufacture and Distribution of Coal Gas; Its Introduction and Progressive Improvement, John Weale, London.

Clow, A. and Clow, N. L. 1970/1952, The Chemical Revolution: A Contribution to Social Technology, Batchworth Press, London.

Crookes, W. 1863, Chemical Products - The Application of Waste, The Popular Science Review, vol. II, no. 5, pp. 58-70.

Crookes, W. and Röhrig, E. 1870, A Practical Treatise on Metallurgy, Longmans, Green, and Co., London.

Crory, W. G. 1876, East London Industries, Longmans, Green, and Co., London.

Descriptive Catalogue of the Collection Illustrating the Utilization of Waste Products, 1875, for Bethnal Green Branch of the South Kensington Museum, George E. Eyre and William Spottiswoode for Her Majesty’s Stationery Office, London.

Desrochers, P. Forthcoming, Did the Invisible Hand Need a Regulatory Glove to Develop a Green Thumb? Some Historical Perspective on Market Incentives, Win-Win Innovations and the Porter Hypothesis. Environmental and Resource Economics.

Desrochers, P. 2007, How Did the Invisible Hand Handle Industrial Waste? By-Product Development Before the Modern Environmental Era, Enterprise and Society, vol. 8, no. 2, pp. 348-74.

Desrochers, P. 2002, Industrial Ecology and the Rediscovery of Inter-Firm Recycling Linkages: Historical Evidence and Policy Implications, Industrial and Corporate Change, vol. 11, no. 5, pp. 1031-1057. 
Deutz, P. and Gibbs, D. 2004, Eco-Industrial Development and Economic Development: Industrial Ecology or Place Promotion?, Business Strategy and the Environment, vol. 13, no. 5, pp. 346-62.

Dodd, G. Penny Wisdom, 1852, Household Words, 16 October, no. 134, pp. 97-101.

Findlay, A. 1917, The Treasures of Coal Tar, D. Van Nostrand Company, New York.

Gale, W. K. V. 1996/1990, Ferrous Metals in McNeil, I. ed., An Encyclopedia of the History of Technology, Routledge, London and New York, pp. 146-85.

Gluud, W. 1932, International Handbook of the By-Product Coking Industry, Ernest Benn Limited, London.

Green, A. C. 1902, The Relative Progress of the Coal-Tar Industry in England and Germany During the Past Fifteen Years, Science, vol. 15, no. 366, pp. 7-13.

Greysmith, D. 2004, “Simmonds, Peter Lund (1814-1897)," Oxford Dictionary of National Biography, Oxford University Press, Oxford, [Online] Available at http://www.oxforddnb.com/view/article/41011, Accessed 15 Dec 2006.

Greysmith, D. 1990, The Empire as Infinite resource: The work of P. L. Simmonds (18141897), Journal of Newspaper and Periodical History, vol. 6, pp. 3-15.

Haber, L. F. 1969/1958, The Chemical Industry During the Nineteenth Century, Oxford University Press, Oxford.

Her Majesty's Jubilee - A Scientific Retrospect, 1887, Chemical News, 1 July, vol. 55, no. 1440, pp. 299-300.

Hunt, R. 1867, Ure's Dictionary of Arts, Manufactures and Mines, Longmans, Green, and Co., London.

Hydraulic Cement from Blast Furnace Slag, 1885, The Manufacturer and Builder, vol. 17, no. 4, pp. 85-86.

Jacobsen, N. B. and Anderberg, S. 2004, Understanding the Evolution of Industrial Symbiotic Networks in Van den Bergh $\mathbf{J}$ and Janssen $\mathbf{M}$ A eds., Economics of Industrial Ecology, Materials, Structural Change, and Spatial Scales, MIT Press, Cambridge, pp. 313-335.

Kershaw, J. B. C. 1928, The Recovery and Use of Industrial and Other Waste, Ernest Benn Limited, London. 
Krook, J., Mårtensson, A. and Eklund, M. 2006, Preservative-Treated Sawn Timber in Sweden: Waste Beyond Control, Progress in Industrial Ecology, vol. 8, no. 3, pp. 47186.

Landy, M. and Cass, L. 1997, US Environmental Regulation in a More Competitive World in Nivola, P. S. eds., Comparative Disadvantages: Social Regulations and the Global Economy, Brookings Institution Press, Washington, pp. 203-41.

Lange, K. R. 1915, The By-Products of Coal Gas Manufacture, Scott, Greenwood \& Sons, London.

Lewes, V. B. 1912, The Carbonisation of Coal: A Scientific Review of the Formation, Composition and Destructive Distillation of Coal, J. Allan and Company, London.

Lock CG Warnford 1884 Workshop Receipts (Third Series) E. \& F.N. Spon, London.

Lowy, A. 1931, Industrial Organic Chemicals and Dye Intermediates in Rogers, A. ed., Industrial Chemistry Volume II: Organic, D. Van Nostrand, New York, pp. 642-724.

Lunge, G. 1887, Coal Tar and Ammonia, Gurney and Jackson, London.

Lyons, D. 2007, A Spatial Analysis of Loop Closing Among Recycling, Remanufacturing, and Waste Treatment Firms in Texas, Journal of Industrial Ecology, vol. 11, no. 1, pp. 43-54.

Mason, J. 1879, The Year-Book of Facts in Science and the Useful Arts for 1879, Ward, Lock and Co., London.

Meiners, R. E. and Yandle, B. 1999, Common Law and the Conceit of Modern Environmental Policy, George Mason Law Review, vol. 7, no. 4, pp. 923-63.

Meiners, R. E. and Morriss, A. P. (eds.) 2000, The Common Law and the Environment: Rethinking the Statutory Basis for Modern Environmental Law, Rowan \& Littlefield Publishers, Inc., New York.

Meldola, R. 1905, Coal and What We Get From It. A Romance of Applied Science. Expanded from the Notes of a Lecture Delivered in the Theatre of the London Institution, Jan. $20^{\text {th }}$, 1890, London (etc.) Society for Promoting Christian Knowledge, New York.

Mosley, S. 2001, The Chimney of the World: A History of Smoke Pollution in Victorian and Edwardian Manchester, The White Horse Press, Cambridge.

Newbigging, T. 1887, Speeches and Addresses. Political, Social, Literary, John Heywood, Manchester and London.

Nothing is Useless, 1849, Chambers' Edinburgh Journal, no. 132, pp. 19-21. 
Noyes, W. A. 1907, The Contribution of Chemistry to Modern Life, Science, vol. 26, no. 673, pp. 706-14.

Nursey, P. F. 1875, The Economic Use of Blast-Furnace Slag, Van Nostrand's Eclectic Engineering Magazine, vol. 12, no. 73, pp. 401-409.

Patent Fuel, 1872, Van Nostrand's Engineering Magazine, vol. 38, no. 6, pp. 160-162.

Paul, E. F. 1980, Laissez faire in nineteenth-century Britain: Fact or myth?, Literature of Liberty, vol. iii, no. 73, pp. 1-71.

Perry, G. P. 1908, Wealth From Waste; or, Gathering up the Fragments, Fleming H. Revell Company, New York.

Playfair, L. 1892, Waste Products Made Useful, North American Review, vol. 155, no. 432, pp. $560-68$.

Playfair, L. 1852, On the Chemical Principles Involved in the Manufactures of the Exhibition as Indicating the Necessity of Industrial Instruction, Society for the Encouragement of Arts, Manufactures and Commerce, London.

Price, E. D. (ed.) 1886, Utilisation of 'Waste Materials' in Hazell's Annual Cyclopedia, Hazell, Watson, and Viney, London.

Reid, H. G. (ed.) 1881, Middlesbrough and its Jubilee: A History of the Iron and Steel Industries with Biographies of Pioneers. "The Gazette" Printing and Publishing Offices, Middlesbrough-on-Tees.

Reports of Engineering Societies, 1879, Van Nostrand's Eclectic Engineering Magazine, vol. 20, pp. 177.

Richardson, B. A. 1993, Wood Preservation, Second Edition, Taylor \& Francis, London.

Russell, C. A. (ed.) 2000, Chemistry, Society and Environment: A New History of the British Chemical Industry, Royal Society of Chemistry, Cambridge.

Shadle, L. J., Barry, D. A. and Syamla, M. 2004, Coal Conversion Processes, Gasification in Kroschwitz, J. I. et al. (eds.), Kirk-Othmer Encyclopedia of Chemical Technology, Vol. 6, John Wiley \& Sons, Hoboken (NJ), pp. 771-832.

Simmonds, P. L. 1883, The Savings of Science, Popular Science Monthly, vol. XXIII, no. II, pp. 798-811.

Simmonds, P. L. 1876/1873, Waste Products and Undeveloped Substances; A Synopsis of Progress Made in their Economic Utilisation during the Last Quarter of a Century at Home and Abroad, Third Edition, Hardwicke and Bogue, London. 
Simmonds, P. L. 1875, Animal Products: Their Preparation, Commercial Uses and Value, Scribner, Welford and Armstrong, New York.

Simmonds, P. L. 1862, Waste Products and Undeveloped Substances; or, Hints for Enterprise in Neglected Fields, Robert Hardwicke, London.

Singer, C. J., Hall, R. A., Williams, T. I. and Holmyard, E. J. (eds.) 1954-1978, A History of Technology, Seven Volumes, Clarendon Press, Oxford.

Smil, V. 2005, Creating the Twentieth Century: Technical Innovations of 1867-1914 and Their Lasting Impact, Oxford University Press, New York.

Stansfield, E. and Carter, E. F. 1915, Products and By-Products of Coal, Department of Mines, Government of Canada, Ottawa.

Talbot, F. A. 1920, Millions From Waste, J. B. Lippincott Company, Philadelphia.

The Utilization of the Molten Mineral Products of Smelting Furnaces, 1855, Journal of the Society of Arts, vol. 3, pp. 355-341.

The Utilization of Slag, 1873, Engineering, vol. 7, pp. 170.

The Value of Rubbish, 1851, Chambers' Edinburgh Journal, no. 385, pp. 310-314. (Reprinted 1851, The Living Age, vol. 30, no. 374, pp. 122-126)

Travis, A. S. 1993, The Rainbow Makers: The Origins of the Synthetic Dyestuffs Industry in Western Europe, Lehigh University Press, Bethlehem (PA).

Utilisation of Waste Products, 1894, Chambers’ Journal, 15 September, pp. 591-92.

Utilization of Blast-Furnace Slag, 1880, Kansas City Review of Science, vol. 3, no. 10, pp. 624625.

Utilization of Coal Waste, 1876, The Manufacturer and Builder, vol. 8, no. 7, pp. 159.

Utilization of Wastes, 1880, The Manufacturer and Builder, vol. 12, no. 4, pp. 36.

Utilization of Waste Products, 1881, The Manufacturer and Builder, vol. 13, no. 4, pp. 86.

Winter, J. 1999, Secure from Rash Assault: Sustaining the Victorian Environment, University of California Press, Berkeley.

Weber, M. and Hemmelskamp, J. 2005, Towards Environmental Innovation Systems, Springer, Berlin. 
Wood, C. 1877, The Utilisation of Slag, Engineering, vol. 24, 28 September, pp. 247-48.

Wright, L. T. 1886, What Shall we do With Our Tar? The Journal of the Society of Chemical Industry, vol. 5, pp. 558-65. 